\title{
Effect of Degradation Time on Carotene Content in Crude Carotene Extract of Carrot for the Formation of its Derivative Aromatic Compounds
}

Daimon Syukri', Rini', Wellyalina', Nika Rahma Yanti², Jaswandi ${ }^{3}$

10.18805/IJARe.A-649

\begin{abstract}
Background: The difference in degradation time on the formation of carotene's derivative aromatic compounds [ $\beta$-ionone and dihydroactinidiolide $(\mathrm{dhA})$ ] due to thermal degradation process of carotenes in crude carotenoid extract of carrot was studied.

Methods: $\beta$-ionone and dhA formation and that of carotenes degradation during thermal degradation $\left(T=140^{\circ} \mathrm{C}\right)$ was observed periodically for $4 \mathrm{~h}$. The constant oxygen supply during degradation was maintained at approx. $7 \mathrm{~L} / \mathrm{h}$.

Result: The formation of $\beta$-ionone and dhA accumulated significantly with increasing duration of the degradation process. The maximum formation of $\beta$-ionone and dhA could be estimated with the pattern of carotenes degradation. After $4 \mathrm{~h}$ of degradation, more than $80 \%$ carotene has degraded. It can be concluded that the degradation process of crude carotene extract from carrots at temperature of $140^{\circ} \mathrm{C}$ will result in a maximum carotene degradation process when the degradation process is carried out for $5 \mathrm{~h}$.

Key words: Carotene, Carrot, Derivative aromatic compounds, Fragrant.
\end{abstract}

\section{INTRODUCTION}

The fragrance industry's demand for raw materials is currently on the rise (Jugreet et al. 2021). Fragrance raw materials are usually produced synthetically and/or extracted from natural or agricultural sources. In comparison to synthetic raw materials, the need for natural raw materials would undoubtedly be more suitable. The distillation method is commonly used to remove fragrances from natural or crops (Burger et al. 2019). Since the yield of fragrances in natural ingredients is only $1-3$ per cent, this process is known to require a large amount of raw materials (Stratakos and Kidis 2016).

To overcome this problem, a technology on process engineering has been developed to obtain fragrances without extraction from natural materials. The change of secondary metabolite compounds that have high yields in natural substances into aromatic compounds can be considered for this situation. As theoretically, the changing B-carotene compounds into raw materials for obtaining $\beta$ ionone and dhA compounds have been introduced (Zepka et al., 2014). Carotenes including $\beta$-carotene are pigments that are mainly contained in several plants or crops such as oil palm, carrots, maize kernels and papaya (Pandey et al. 2003; Panghal et al. 2009; Pitambara and Nagarajan, 2016; Syukri and Chamel, 2021). This compound is present in large quantities and is not categorized as an aromatic compound. Meanwhile $\beta$-ionone and $\mathrm{dh} A$ are derivative compounds that can be produced by the process of oxidation carotene compounds. This compound is one of the aromatic compounds that are widely used as fragrances in processed products such as soap, shampoo and even food.

There have been many studies that have developed regarding the conversion of $\beta$-carotene to ionone and $\mathrm{dhA}$.
1Department of Agricultural Product Technology Andalas University, Padang, 25163, Indonesia.

${ }^{2}$ Department of Agricultural Engineering and Biosystem Andalas University, Padang, 25163, Indonesia.

${ }^{3}$ Department of Animal Production Andalas University, Padang, 25163, Indonesia.

Corresponding Author: Daimon Syukri, Department of Agricultural Product Technology Andalas University, Padang, 25163, Indonesia. Email: dsyukri@ae.unand.ac.id

How to cite this article: Syukri, D., Rini, Wellyalina, Yanti, N.R. and Jaswandi (2021). Effect of Degradation Time on Carotene Content in Crude Carotene Extract of Carrot for the Formation of its Derivative Aromatic Compounds. Indian Journal of Agricultural Research. DOI: 10.18805/IJARe.A-649.

Submitted: 04-05-2021 Accepted: 24-08-2021 Online: 06-09-2021

The conversion of $\beta$-carotene to $\beta$-ionone and $\mathrm{dhA}$ can be carried out chemically (oxidation) or enzymatically (Czajka et al., 2018; Perveen et al., 2019). To obtain $\beta$-carotene, it is necessary to carry out the process of isolating $\beta$-carotene from crude carotene extracts produced from agricultural materials. Carrying out the isolation process would require a considerable amount of effort and would be impractical in practice. The use of carotene crude extract without $\beta$-carotene isolation has also been done previously. The study concluded that the degradation process of crude carotene extract can also be used as a base material for obtaining $\beta$-ionone and $\mathrm{dhA}$. The information obtained from this study is still limited. The research results only inform that the best condition for the degradation process is the thermal degradation process at a temperature of $140^{\circ} \mathrm{C}$ for $4 \mathrm{~h}$ (Hazrulrizawati et al. 2017). There is no information yet about 
the degradation patterns of $\beta$-carotene and the patterns of $\beta$-ionone and $\mathrm{dhA}$ formation that occur. Therefore, in this study that matter will be clarified.

The process of $\beta$-ionone and dhA formation is carried out by thermal degradation from the crude carotene extract of carrot. The degradation process was carried out at a temperature of $140^{\circ} \mathrm{C}$ for 4 hours. The pattern of carotene degradation and ionone and $\mathrm{dhA}$ formation will be observed periodically. This data will be useful in developing this process on a pilot scale in the future.

\section{MATERIALS AND METHODS}

The study was arranged at the laboratory of Food and Agricultural Product's Phytonutrient, Department of Agricultural Product Technology and the laboratory of Animal Biotechnology, Department of Animal Production Andalas University, Indonesia on from February 2021 to May 2021.

\section{Samples preparation}

The dried carrots were made by soft heating of ground fresh carrots at a low temperature $\left(60^{\circ} \mathrm{C}\right)$ until the moisture content was about $15 \%$.

\section{Carotene extraction}

The extraction of carotene was conducted according Rifki et al. 2020 with modifications. A $200 \mathrm{~mL}$ hexane was applied to $100 \mathrm{~g}$ of dried sample. After that, the mixture was homogenized. Maceration was used to extract the carotenoid. The maceration process was supported by the use of an ultrasonic apparatus for $4 \mathrm{~h}$ and then proceeded without the use of the sonication method for another $8 \mathrm{~h}$. The liquid phase was isolated from the residue after the mixture was filtered. The maceration process for the residue was repeated every 12 hours until the sample's color changed from orange to white, indicating that all of the carotene had been removed. The solvent was evaporated with a rotary evaporator until the viscous extract of carotene was obtained.

\section{Thermal degradation of crude carotene extract}

Degradation was carried out according to Hazrulrizawati et al. 2017 with some modification by using a Rancimat 743 apparatus (Herisau, Switzerland) with a temperature range of 80 to $220^{\circ} \mathrm{C}$. A $0.5 \mathrm{~g}$ of Crude carotene extract was weighed and mixed with $4.5 \mathrm{~g}$ of glycerol in a $50 \mathrm{~mL}$ reaction vessel which was then placed in an electric heating block. The instrument was operated at $140^{\circ} \mathrm{C}$ with an air flow rate of $7 \mathrm{~L} / \mathrm{hr}$. The degradation process lasted 4 hours, with hourly sampling intervals. In a measuring vessel containing $10 \mathrm{~mL}$ of ethanol, effluent air containing volatile organic acids, including volatile organic compounds from crude carotene samples, was collected. Until injecting $2 \mathrm{~mL}$ of ethanol into the Gas Chromatography-Mass Spectrometer, it was filtered through a $0.2 \mathrm{M}$ polytetrafluoroethylene membrane filter.

\section{Analysis of total carotene}

In a $25 \mathrm{~mL}$ amber volumetric flask, a viscous extract of 0.1 $\mathrm{g}$ was transferred. The volume was filled with hexane and the sample was measured at $446 \mathrm{~nm}$ with a UV-VIS Spectrophotometer. The total carotenoid content was calculated using the following formula:

Carotenoids content:

$$
\text { Carotene }\left(\frac{\mu \mathrm{g}}{\mathrm{g}}\right)=\frac{25 \times \mathrm{A} \times 383}{100 \times \text { sample weight }(\mathrm{g})}
$$

\section{Where}

$A=$ absorbance at $446 \mathrm{~nm}, 383=$ diffusion coefficient of caroten, $\mathrm{V}=$ value of hexane $(\mathrm{mL})$ and $\mathrm{W}=$ weight of sample (g).

\section{Detection of Aromatic volatile compounds}

The detection of volatile compound was conducted according to Syukri et al. 2019 and Rini et al. 2021 with slight modification. A mass spectrometer (Shimadzu GCMSQP2010 Ultra, Kyoto, Japan) was used to analyze the volatile compounds formed by crude carotene degradation 10,11. Helium served as the carrier gas. The DB-5 MS capillary column (30 m length, $0.25 \mathrm{~mm}$ inner diameter, $0.20 \mathrm{~m}$ film thickness, Agilent, USA) was used for matrix separation. The injector temperature was set to $220^{\circ} \mathrm{C}$, the column oven temperature was raised from $60^{\circ} \mathrm{C}$ to $260^{\circ} \mathrm{C}$ and the detector interface temperature was set to $270^{\circ} \mathrm{C}$. The separation was carried out using the following temperature program: the temperature was set to $60^{\circ} \mathrm{C}$ and held for 4,5 minutes. The temperature was then increased to $130^{\circ} \mathrm{C}$ at a $5^{\circ} \mathrm{C} \mathrm{min}^{-1}$ ramp rate and then to $260^{\circ} \mathrm{C}$ at a $10^{\circ} \mathrm{C} \mathrm{m^{-1 }}$ ramp rate. For 2 minutes, the final column temperature was kept at $260^{\circ} \mathrm{C}$. With split less injection mode, $1 \mathrm{~mL}$ of sample was injected for each sample. A mass spectral library search and a peak area normalization method to compare retention indexes were used to identify compounds. The results of the experiment were validated by repeating it at least three times.

\section{Colour measurement}

The carotenes sample were check for colour changes with a hunterLab. colorFlex EZ. The measurement referred to the method that described by Olgunoglu (2013). The measurement was conducted at least three times.

\section{Analytical statistics}

All determination's results are stated as the average of three replicates. Analysis of variance was used to assess statistical significance and the means were compared using Tukey's test at a $5 \%$ level of significance using R 3.3.2. (R Foundation for Statistical Computing).

\section{RESULTS AND DISCUSSION}

Fig 1 indicates the accumulation of $\beta$-ionone and $\mathrm{dh} A$ relating to carotenes degradation during thermal degradation at $140^{\circ} \mathrm{C}$ for $4 \mathrm{~h}$. The accumulation of $\beta$-ionone and $\mathrm{dh} A$ increased significantly after $2 \mathrm{~h}$ degradation process. $\beta$-ionone increased four times after $4 \mathrm{~h}$ degradation while $\mathrm{dhA}$ increased six times. Previous reports indicated that the formation of dhA would be more than that of $\beta$-ionone 
Effect of Degradation Time on Carotene Content in Crude Carotene Extract of Carrot for the Formation of its Derivative...

Table 1: Carotenes degradation during thermal degradation for $4 \mathrm{~h}$.

\begin{tabular}{lcc}
\hline Time $(\mathrm{h})$ & $\begin{array}{c}\text { Total Carotene } \\
\text { content }\left(\mu \mathrm{g} \cdot \mathrm{mg}^{-1}\right)\end{array}$ & $\begin{array}{c}\text { Carotene } \\
\text { degradation }(\%)\end{array}$ \\
\hline 4 & $1,34 \pm 0,21^{\mathrm{a}}$ & 86,05 \\
3 & $3,49 \pm 0,41^{\mathrm{b}}$ & 63,68 \\
2 & $3,72 \pm 0,81^{\mathrm{b}}$ & 61,29 \\
1 & $6,59 \pm 1,07^{\mathrm{c}}$ & 31,42 \\
0 & $9,61 \pm 1,01^{\mathrm{d}}$ & 0 \\
\hline
\end{tabular}

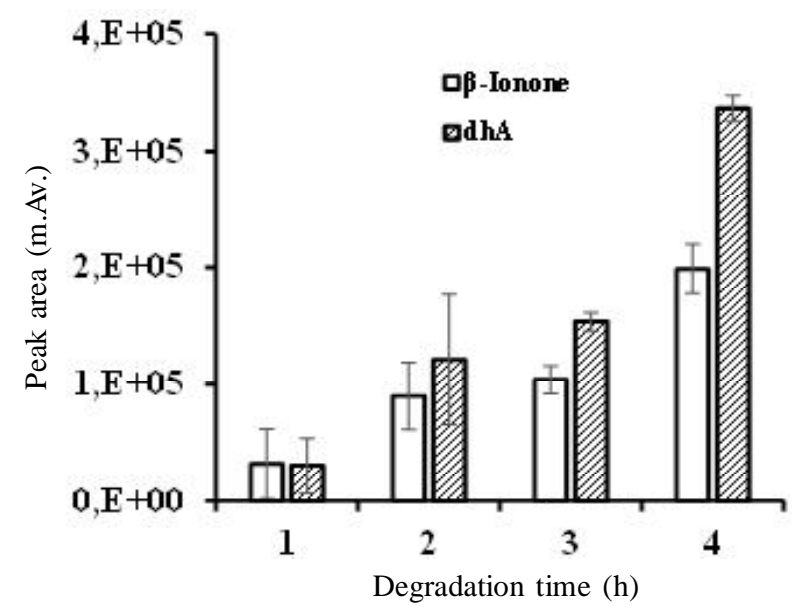

Fig 1: The accumulation pattern of $\beta$-ionone and dhA relating to carotenes degradation during thermal degradation at $140^{\circ} \mathrm{C}$ for $4 \mathrm{~h}$.

(Kanasawut and Crouzet, 1990). The thermal degradation process of $\beta$-carotene isolated from palm oil has formed dhA fifteen times that of $\beta$-ionone. The degradation process of $\beta$-carotene will produce a higher amount of dhA than $\beta$-ionone (Wache et al. 2003; Shumbe et al. 2014; Ge et al. 2015; Hazrulrizawati et al. 2017). According to the proposed $\beta$-carotene degradation pathway, the formation of dhA occurs as the first oxidation product prior to the formation of $\beta$-ionone (Gloria et al., 1993). Although there was another proposed $\beta$ carotene degradation pathways that suggest $\beta$-ionone formation occurs before dhA (Kanasawut and Crouzet, 1990; Sommerburg et al. 2003), the findings of this study suggested that the proposed pathway of Gloria et al. (1993) was more appropriate. Therefore, it can be concluded that the use of thermal reactions in the degradation process of carotene compounds produced $\beta$-ionone lower than dhA.

The degradation pattern of crude carotene during thermal degradations was observed using spectrophotometric analysis. The amount of carotenes that was degraded was influence by time. In this study, the sample used was a non- polar extract of carrot. The extract contains many substances that solved in hexane. The maximum wavelength obtained was $446 \mathrm{~nm}$, indicating the presence of carotene as the main compound of the carrot crude carotene extract (data not shown). Moreover, there was a significant degradation of carotenes during $4 \mathrm{~h}$ of degradation period (Table 1 ). There has been carotene degradation of $30 \%$ in the first hour of the degradation process and continues in the next hour. After $4 \mathrm{~h}$ of degradation period, more than $80 \%$ of the initial carotene was degraded. At initial, there was 9,61 $\mu \mathrm{g} . \mathrm{mg}^{-1}$ of carotene in crude carotene extract of carrot, after $4 \mathrm{~h}$ of degradation only $1,34 \mu \mathrm{g} \cdot \mathrm{mg}^{-1}$ of carotene was detected, therefore it can be estimated that the degradation process of crude carotene to form $\beta$-ionone and dhA might no more than $6 \mathrm{~h}$. The result of this study indicated that carotenes including $\beta$-carotene degraded rapidly due to heat treatment. This result was in agreement with previous research conducted by Hazrulrizawati et al. (2017). However, in contrast with the condition of under light treatment, $\beta$ carotene degraded in low rate as mentioned by Limbo et al. (2007) and Torri et al. (2007). The presence of other nonpolar matrices did not appear to have an effect on the degradation process of $\beta$-carotenes.

Table 2 indicates the colour observation of crude carotene extract of carrot during thermal degradation. The color observation of thermally degraded crude carotenes was observed on Hunter color Lab in the form of Hue, ' $L$ ', ' $a$ ' and ' $b$ ' values. There was an increasing of hue value of treated crude carotene extract thermal degradation from 32 to 39. In line with the carotene degradation pattern, the color change also occurred from orange to yellow which indicates the degradation of the carotene compound. On 'L', 'a' and 'b' values, there was no significant changes during first $3 \mathrm{~h}$ of degradation process however after $4 \mathrm{~h}$ degradation, there was a decreasing of ' $L$ ', ' $a$ ' and 'b' values. These data indicated, as degradation of carotenes occurred, other compounds shift, potentially darkening the color of the mixture. It can be suggested that the degradation of other non-polar compounds such as fatty acids might occurred at this time (at $4 \mathrm{~h}$ degradation). The browning reaction due to the maillard reaction and the formation of acrylamide might also occur due to the presence of non-polar vitamins, fats, proteins and carbohydrates (Reddy and Jialal, 2020; Moran and Johnson, 2017, Aprialis et al. 2021). Although present in a small amount, as a biochemical product, carrot extract also contains fat-soluble parts which will also be extracted during carotene extraction which will then react when the heat degradation process occurred.

Table 2: Colour of crude carotene extract of carrot during thermal degradation.

\begin{tabular}{lccccc}
\hline Time $(\mathrm{h})$ & $\mathrm{L}^{*}$ & $\mathrm{a}^{*}$ & $\mathrm{~b}^{*}$ & $\mathrm{C}$ & ${ }^{\circ} \mathrm{Hue}$ \\
\hline 4 & $6,28 \pm 0,03^{\mathrm{a}}$ & $1,52 \pm 0,03^{\mathrm{a}}$ & $1,24 \pm 0,04^{\mathrm{a}}$ & $1,96 \pm 0,05^{\mathrm{a}}$ & $39,26 \pm 2,75^{\mathrm{b}}$ \\
3 & $9,50 \pm 0,06^{\mathrm{b}}$ & $5,98 \pm 0,03^{\mathrm{c}}$ & $4,65 \pm 0,03^{\mathrm{d}}$ & $7,58 \pm 0,04^{\mathrm{d}}$ & $37,85 \pm 0,21^{\mathrm{b}}$ \\
2 & $9,11 \pm 0,05^{\mathrm{c}}$ & $5,59 \pm 0,05^{\mathrm{b}}$ & $4,26 \pm 0,21^{\mathrm{c}}$ & $7,02 \pm 0,15^{\mathrm{c}}$ & $37,29 \pm 1,23^{\mathrm{b}}$ \\
1 & $8,34 \pm 0,06^{\mathrm{d}}$ & $5,52 \pm 0,04^{\mathrm{b}}$ & $3,51 \pm 0,01^{\mathrm{b}}$ & $6,54 \pm 0,02^{\mathrm{b}}$ & $32,44 \pm 0,24^{\mathrm{a}}$ \\
\hline
\end{tabular}




\section{CONCLUSION}

The formation of $\beta$-ionone and dhA was investigated through a thermal degradation of crude carotene extract of carrot. The formation of dhA was prominent compare to $\beta$-ionone. The process of degradation can be conducted optimally in about 5 hours where in this condition, all carotene has been completely degraded. The finding of this study can be useful in developing appropriate techniques in the utilization of nonaromatic substances from agricultural products to produce aromatic compounds that is useful as an alternative solution to the problem of procuring aromatic compounds which are constrained by the difficulty of raw materials.

\section{AKNOWLEDGEMENT}

The authors would like to acknowledge a research grant from the Institute for Research and Community Service Andalas University for the funding support (T/6/UN.16.17/ PP.Pangan-PDU-KRP2GB-Unand/LPPM/2021). The author also wants to thank Mrs. Dosmawarni Indah Gultom and Ulfi Mairita for assistance in carrying out the research.

\section{REFERENCES}

Aprialis, Kasim. A. and Rini (2021). Characteristics of oil used in frying peanuts, cassava and mackerel tuna. Andalasian International Journal of Agriculture and Natural Sciences. 2(1): 19-24. DOI: 10.25077/aijans.v2.i01.50-62.2021.

Burger, P., Plainfossé, H., Brochet, X., Chemat, F. and Fernandez, X. (2019). Extraction of natural fragrance ingredients: History overview and future trends. Chemistry and Biodiversity. 16. DOI: 10.1002/cbdv.201900424.

Czajka, J., Nathenson, J., Benites, V., Baidoo, E., Cheng, Q., Wang, Y. and Tang, Y. (2018). Engineering the oleaginous yeast Yarrowialipolytica to produce the aroma compound $\beta$-ionone. Microbial Cell Factories. 17. DOI: 10.1186/s12934018-0984-x.

Ge, W., Chen, Y., Wang, L. and Zhang, R. (2015). Photocatalytic degradation of $\beta$-carotene with $\mathrm{TiO} 2$ and transition metal ions doped TiO2 under visible light irradiation. Universal Journal of Chemistry. 3: 104-111. DOI: 0.13189/ujc.2015. 030402.

Gloria. M.B.A, Grulke. E.A and Gray. J.I. (1993). Effect of type of oxidation on $\beta$-carotene loss and volatile products formation in model systems. Food Chemistry. 46: 401406. DOI: 10.1016/0308-8146(93)90012-5.

Hazrulrizawati, A., Hamid. S.K. and Mashitah, M.Y. (2017). Dihydroactinidiolide from thermal degradation of $\beta$ carotene. International Journal of Food Properties. 20(3): 674-680, DOI: 10.1080/10942912.2016.1177071.

Jugreet, S., Mahomoodally, F., Zengin, G. and Maggi, F. (2021). Essential oils as natural sources of fragrance compounds for cosmetics and cosmeceuticals. Molecules. 26. DOI: 10.3390/molecules26030666.

Kanasawut, Pawinee and Crouzet, J.C. (1990). Mechanism of formation of volatile compounds by thermal degradation of carotenoids in aqueous medium. 1. $\beta$-carotene Degradation. J. Agric. Food Chem. Vol. 38, No. 1. DOI: $10.1021 /$ jf00091a052.
Limbo S, Torri, L. and Piergiovanni, L. (2007). Light-induced changes in an aqueous beta-carotene system stored under halogen and fluorescent lamps, affected by two oxygen partial pressures. J. Agric Food Chem. 27; 55(13): 5238-45. Epub 2007 Jun 1. PMID: 17539657. DOI: 10.1021/jf06 34348.

Moran, N.E. and Johnson, E.J. (2017). Closer to clarity on the effect of lipid consumption on fat-soluble vitamin and carotenoid absorption: Do we need to close in further? The American Journal of Clinical Nutrition. 106(4): 969-970. https:// doi.org/10.3945/ajcn.117.165894.

Olgunoglu, İ. (2013). Determination of color characterization in some economical freshwater fish species fillets during iced storage for 24 days. Indian Journal of Animal Research. 47: 187-195.

Pandey, D., Rajput, A. and Kulshrestha, K. (2003). Carotene rich food supplements based on carrot powder. Asian Journal of Dairy and Food Research. 22: 239-241.

Panghal, R., Jood, S. and Khetarpaul, N. (2009). Sensory and nutritional evaluation of cookies developed using crude palm oil, safflower oil and their blends. Journal of Dairying, Foods and Home Sciences. 28(1): 14-19.

Perveen, I., Raza, M., Sehar, S., Naz, I. and Ahmed, S. (2019). Purification of recombinant peroxidase from Thermobifidafusca IP1 for $\beta$-carotene degradation into industrial flavouring agents. International Food Research Journal. 26. 731736. Available form:ifrj.upm.edu.my/26\%20(02)\%202019/ (40).pdf.

Pitambara and Nagarajan, P. (2016). Identification of high $\beta$-Carotene lines of maize in backcross (BC2F1) population by genotyping crtRB1 Allele specific marker. Indian Journal of Agricultural Research. 50: 434-439. DOI: 10.18805/ ijare.v0iOF.3755.

Reddy P. and Jialal, I. Biochemistry, Fat Soluble Vitamins. [Updated 2020 Sep 21]. In: StatPearls [Internet]. Treasure Island (FL): StatPearls Publishing; 2021 Jan-. Available from: https://www.ncbi.nlm.nih.gov/books/NBK534869/.

Rini, B., Kasim, A., Kata, T. T. and Syukri, D. (2021). Production of wood varnish from ambalau resin of Durio zibethinus (Murr.): A Preliminary Study. Asian Journal of Plant Sciences. 20: 116-121. DOI: 10.3923/ajps.2021. 116.121.

Shumbe, L., Bott, R. and Havaux, M. (2014). Dihydroactinidiolide, a high light-induced $\beta$-carotene derivative that can regulate gene expression and photoacclimation in arabidopsis. Molecular Plant. 7. DOI:10.1093/mp/ssu028.

Stratakos, A.C. and Koidis, A. (2016). Methods for Extracting Essential Oils. In: Essential Oils in Food Preservation, Flavor and Safety, Academic Press. (pp. 31-38).

Sommerburg, O., Langhans, C.D., Arnhold, J., Leichsenring, M., Salerno, C., Crifò, C. and Siems, W.G. (2003). $\beta$-Carotene cleavage products after oxidation mediated by hypochlorous acid-A model for neutrophil-derived degradation. Free Radical Biology and Medicine. 35(11): 1480-1490.

Syukri, D., Thammawong, M., Naznin, H.A.and Nakano, K. (2019). Role of raffinose family oligosaccharides in respiratory metabolism during soybean seed germination. Environ. Control Biol. 57(4): 107-112. DOI: 10.2525/ecb. 57.107 . 
Effect of Degradation Time on Carotene Content in Crude Carotene Extract of Carrot for the Formation of its Derivative...

Syukri, D and Chamel, A. (2021). The enhancement of phytochemical compounds in fresh produces by abiotic stress application at postharvest handling stage. Andalasian International Journal of Agriculture and Natural Sciences. 2(1): 1-18. DOI: 10.25077/aijans.v2.i01.1-18.2021.

Torri, L., Piergiovanni, L and Limbo, S. (2007). Degradation of $\beta$ carotene in an aqueous medium exposed to fluorescent and halogen light under different oxygen partial pressure. Italian Journal of Food Science. 19. 62-67.
Waché, Y., Bosser-DeRatuld, A., Lhuguenot, J. and Belin, JeanMarc. (2003). Effect of cis / trans isomerism of $\beta$-Carotene on the ratios of volatile compounds produced during oxidative degradation. Journal of Agricultural and Food Chemistry. 51: 1984-7. DOI: 10.1021/jf021000g.

Zepka, L., Garruti, D., Sampaio, K., Mercadante, A. and Silva, M. (2014). Aroma compounds derived from the thermal degradation of carotenoids in a cashew apple juice model. Food Research International. 56. 108-114. DOI: 10.1016/ j.foodres.2013.12.015. 